\title{
METABOLIC EFFECTS OF ANAESTHESIA: \\ EFFECT OF THIOPENTONE-NITROUS OXIDE ANAESTHESIA ON HUMAN GROWTH HORMONE AND INSULIN LEVELS IN PLASMA*
}

\author{
T. Oyama, M.D., M. TAKiguchi, M.D., ANd T. Kudo, B.s.
}

General anAesthesia and surgery in man are often accompanied by reflex endocrine stimulation releasing substances such as catecholamines, АСтH, and corticosteroids. The metabolic changes occurring during stress have been attributed in part to these hormonal influences. Recently the participation of growth hormone (HGH) of the anterior pituitary gland in carbohydrate and fat metabolism has received attention. Oyama and associates ${ }^{1,2}$ have recently found significant elevation of HGH in the plasma during ether and methoxyflurane anaesthesia.

It is well known that thiopentone combined with nitrous oxide anaesthesia in the absence of surgery induces no hyperglycaemia., ${ }^{3,4}$ Henneman and Bunker ${ }^{3}$ observed that thiopentone produced a significant reduction in tolerance to administered glucose. However, no study of the actual effects of thiopentone-nitrous oxide anaesthesia on plasma insulin and growth hormone (HGH) has been reported.

The present study was designed to investigate the effects of thiopentone-nitrous oxide anaesthesia on carbohydrate and fat metabolism by glucose load, as judged by its influence on plasma growth hormone, insulin, blood glucose, free fatty acids (FFA), and to compare this with the effects of anaesthesia plus surgery. Glucose infusion is a method of looking at carbohydrate metabolism under stress states. ${ }^{\mathbf{a}-\bar{t}}$.

\section{METHOD}

Thirty-three patients, ranging in age from 19 to 66 years and free from endocrine hepatic, and renal disease, were the subjects of the study. They were divided into two groups. One was a group of 20 patients who were anaesthetized and the other was a control group of 13 patients who underwent neither anaesthesia nor surgery. All subjects studied received no food or water for at least 12 hours prior to induction of anaesthesia. They were given pentobarbital $100 \mathrm{mg}$ by mouth $1 \frac{1}{2}$ hours before anaesthesia, and pethidine $35 \mathrm{mg}$ with atropine $0.5 \mathrm{mg}$ intramuscularly 1 hour before anaesthesia. The control group did not receive these preanaesthetic medicacations.

Thiopentone-nitrous oxide-oxygen anaesthesia was induced with injection of thiopentone sodium (Pentothal), approximate $200 \mathrm{mg}$ in divided doses supplemented with nitrous oxide $(4 \mathrm{~L} / \mathrm{min})$ plus oxygen $(2 \mathrm{~L} / \mathrm{min})$. Succinylcholine chloride $40 \mathrm{mg}$ was given intravenously to provide muscle relaxation sufficient for endotracheal intubation.

General anaesthesia was maintained with nitrous oxide at a flow of $3.5 \mathrm{~L} / \mathrm{min}$

\footnotetext{
"Department of Anaesthesia, Hirosaki University School of Medicine, Hirosaki, Aomori-Ken, Japan.
} 
TABLE I

\section{Patients Studied and Operation Performed}

\begin{tabular}{|c|c|c|c|c|c|c|}
\hline Cases & Age & Sex & Performed Operation & $\begin{array}{l}\text { Duration } \\
\text { of Ope. (hr) }\end{array}$ & $\begin{array}{l}\text { Duration } \\
\text { of Ane. (hr) }\end{array}$ & $\begin{array}{l}\text { total } \\
\text { thiopent. (mg) }\end{array}$ \\
\hline 1 & 28 & $\mathbf{F}$ & Hysterectomy & 1.40 & 3.00 & 650 \\
\hline 2 & 64 & $\mathbf{M}$ & Gastrectomy & 1.35 & 3.00 & 540 \\
\hline 3 & 46 & $\mathbf{F}$ & Hysterectomy & 2.15 & 4.10 & 1100 \\
\hline 4 & 59 & $\mathbf{F}$ & Gastrectomy & 1.50 & 3.55 & 700 \\
\hline 5 & 50 & $\mathbf{F}$ & Hysterectomy & 3.05 & 3.50 & 525 \\
\hline 6 & 52 & $\mathbf{F}$ & Hysterectomy & 4.10 & 4.55 & 650 \\
\hline 7 & 66 & $\mathbf{F}$ & rectal amputation & 4.05 & 5.30 & 700 \\
\hline 8 & 62 & $\mathrm{~F}$ & Hysterectomy & 2.00 & 3.35 & 800 \\
\hline 9 & 50 & $\mathbf{F}$ & Hysterectomy & 3.25 & 4.25 & 850 \\
\hline 10 & 25 & M & Tendoplasty & 3.00 & 4.20 & 1000 \\
\hline 11 & 44 & $\mathbf{F}$ & Hysterectomy & 3.50 & 4.30 & 700 \\
\hline 12 & 38 & M & Gastrectomy & 2.25 & 3.35 & 950 \\
\hline 13 & 35 & M & Gastrectomy & 4.10 & 4.55 & 900 \\
\hline 14 & 33 & $\mathbf{F}$ & Extirpation of myom & 2.05 & 3.00 & 600 \\
\hline 15 & 60 & $\mathbf{F}$ & Ligamentopexia & 1.30 & 2.30 & 800 \\
\hline 16 & 19 & $\mathbf{F}$ & Removal of Stainless plate & 1.30 & 2.40 & 550 \\
\hline 17 & 59 & $\mathbf{F}$ & Hysterectomy & 2.35 & 3.15 & 750 \\
\hline 18 & 43 & $\mathbf{F}$ & Hysterectomy & 3.20 & 4.20 & 850 \\
\hline 19 & 48 & $\mathrm{~F}$ & Hysterectomy & 1.35 & 2.25 & 650 \\
\hline 20 & 42 & $F$ & Hysterectomy & 2.40 & 3.30 & 600 \\
\hline \multicolumn{3}{|c|}{ Mean } & & 2.38 & 3.46 & 743 \\
\hline
\end{tabular}

and oxygen at a flow of $1.5 \mathrm{~L} / \mathrm{min}$. Subsequent doses of thiopentone sodium 50 to $100 \mathrm{mg}$ were injected when nceded. An approximate total of $500 \mathrm{mg}$ was administered over 45 minutes of anaesthesia alone, before operation. Respiration was assisted or controlled intermittently throughout the procedure. Tubocurarine (15$30 \mathrm{mg}$ ) in divided doses was used for muscle relaxation during intra-abdominal surgery (Table I).

The avcrage operating time was 2 hours and 38 minutes ( 1 hour 30 minutes to 4 hours 10 minutes), the average duration of anaesthesia was 3 hours and 46 minutes ( 2 hours 25 minutes to 5 hours 30 minutes). The average dose of thiopentone was $743 \mathrm{mg}$ ( 525 to $1100 \mathrm{mg}$ ). Low molecular weight dextran (Rheomacrodex) $500 \mathrm{ml}$ containing $25 \mathrm{gm}$ of glucose was infused throughout the course of the procedure in both groups. Approximately $10 \mathrm{gm}$ of glucose was infused during the 45 minutes of anaesthesia alone, and this rate of glucose infusion was maintained throughout the procedure. Whole blood was transfused when blood loss exceeded $500 \mathrm{ml}$. In the control group $25 \mathrm{gm}$ of glucose $(500 \mathrm{ml}$ of 5 per cent dextrose and 10 per cent dextran in distilled water) was infused for $1 \gamma_{2}^{\prime}$ hours.

Nine blood samples were obtaincd at the following times: (1) $8.30 \mathrm{am}$, just prior to induction (This served as a control value.); (2) 15, 30, and 45 minutes after anaesthesia alone or equivalent time in the control group; (3) 15 and 30 minutes, 1 hour, and 2 hours after the start of operation or 1, 1/2, and 2 hours after the start of infusion in the control group; (4) when the patient had fully awakened in the recovery room. Five $\mathrm{ml}$ of venous blood was collected on each occasion in a heparin- 
ized syringe, rapidly transferred to a tube, then centrifuged within 30 minutes of collection. One $\mathrm{ml}$ of plasma was kept at $-20^{\circ} \mathrm{C}$, and thawed within one month, just prior to radio-immuno-assay for growth hormone and insulin. One $\mathrm{ml}$ of plasma was kept at $4^{\circ} \mathrm{C}$ for analysis of FFA (free fatty acid = nonesterified fatty acids (NEFA)), and $0.2 \mathrm{ml}$ of plasma was used to measure blood glucose.

Plasma growth hormone (HGH) was measured according to the method of Schalch and Parker. ${ }^{8}$ The analysis of plasma insulin was made after the method of Morgan and Lazarow, ${ }^{9}$ which utilized $\mathbf{I}^{125}$. Duplicate determinations were made on all specimens and the mean values were taken. The recovery rate for HGH and insulin was 98 per cent and 94 per cent respectively, by our method, which indicates reliability of the methods. The blood glucose was measured by the method of Somogyi ${ }_{10}^{10}$ and plasma FFA was determined by colorimetric method of Dumcombe. ${ }^{11}$

\section{RESULTS}

\section{Plasma Growth Hormone}

Mean plasma growth hormone ( $\mathbf{H G H}$ ) in 13 control patients is shown in Table II. It increased from 1.4 to $3.0 \mathrm{~m} \mu \mathrm{g} / \mathrm{ml}$, but these changes were not statistically significant. Plasma HGH level in 20 patients after receiving premedication, immediately before induction of anaesthesia was $1.3 \mathrm{~m} \mu \mathrm{g} / \mathrm{ml}$, which was within normal limit (less than $5.0 \mathrm{~m} \mu \mathrm{g} / \mathrm{ml}$ ). The HGH levels in plasma did not change appreciably during anaesthesia alone and it was $1.5 \mathrm{~m} \mu \mathrm{g} / \mathrm{ml} 45$ minutes after the induction of anaesthesia, as shown in Table III and Figure 1. The plasma level of HGr rose significantly to $7.3 \mathrm{~m} \mu \mathrm{g} / \mathrm{ml} 30$ minutes after the start of operation, and it rose further to make a peak level 1 hour after the start of surgery. It gradually fell in the postoperative period.

\section{Plasma Insulin}

The mean insulin levels in plasma in the control group increased from 17.8 to $27.0 \mu \mathrm{U} 30$ minutes after starting glucose infusion and it rose significantly to $22.9 \mu \mathrm{v} / \mathrm{ml} 45$ minutes after starting the infusion. It remained elevated during infusion, then fell 30 minutes after termination of the glucose infusion (Table II). The mean preanaesthetic plasma insulin level in 20 patients was $12.5 \mu \mathrm{v}$, which was within normal limits $(5-35 \mu \mathrm{v} / \mathrm{ml})$. The plasma insulin level did not change appreciably during anaesthesia alone or during surgery as shown in Table IV and Figure 1.

\section{Blood glucose and FFA}

(1) The blood glucose under glucose load in the control group increased signifcantly from $80.7 \mathrm{mg} / 100 \mathrm{ml}$ of pre-infusion level to $115 \mathrm{mg} / 100 \mathrm{ml}$ and $128.4 \mathrm{mg} /$ $100 \mathrm{ml}$ during 45 minutes and $1 \frac{1}{2}$ hours respectively of glucose infusion as shown in Table II. Due to the glucose infusion during anaesthesia, blood glucose rose significantly from the preinduction control level of $92.2 \mathrm{mg} / 100 \mathrm{ml}$ to $135.3 \mathrm{mg} /$ $100 \mathrm{ml}$ after 45 minutes of anaesthesia alone as shown in Table V. It continued to rise further to $169.5 \mathrm{mg} / 100 \mathrm{ml} 2$ hours after start of operation (Figure 2).

(2) The mean blood FFA level in the control group varied from $442 \mu \mathrm{Eq} / \mathrm{L}$ to 


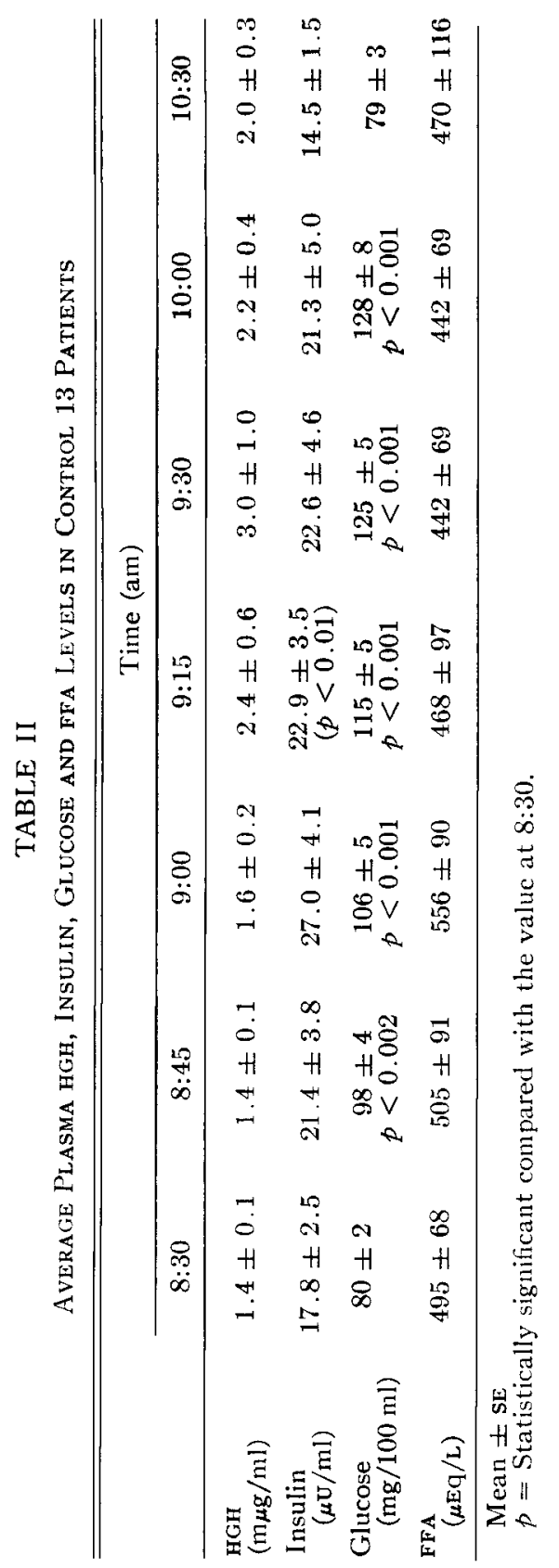


TABLE III

\section{Plasma HGH Levels During Thiopent- $\mathrm{N}_{2} \mathrm{O}$ Anesthesia and Surgery}

\begin{tabular}{|c|c|c|c|c|c|c|c|c|c|}
\hline \multirow{2}{*}{ Subjects } & \multicolumn{9}{|c|}{ Plasma HGH Lovels (mug/ml) } \\
\hline & Pre-ind & Ane $15^{\prime}$ & $30^{\prime}$ & $45^{\prime}$ & Op. 15' & $30^{\prime}$ & $60^{\prime}$ & $120^{\prime}$ & R.R. \\
\hline 1 & 1.7 & 4.0 & 0.7 & 2.0 & - & 3.7 & 6.0 & - & 7.3 \\
\hline 2 & 4.3 & 2.3 & 2.3 & - & 4.3 & 3.7 & 7.3 & - & 22.0 \\
\hline 3 & 1.3 & 1.7 & 1.0 & 1.0 & - & 12.5 & 8.0 & - & 1.0 \\
\hline 4 & 2.0 & 2.0 & 2.3 & 2.0 & 12.0 & 50.0 & 73.5 & - & 4.7 \\
\hline 5 & 2.3 & 2.0 & 1.7 & 2.3 & 2.3 & 10.0 & 12.5 & 6.7 & 4.7 \\
\hline 6 & 1.0 & 1.7 & 1.0 & 1.7 & 1.7 & 2.0 & 5.3 & 3.0 & 2.3 \\
\hline 7 & 1.7 & 1.7 & 1.7 & 2.7 & 3.7 & 11.7 & 10.0 & 3.0 & 1.0 \\
\hline 8 & 2.3 & 1.0 & 1.7 & - & 1.7 & 9.3 & 13.3 & 7.3 & 3.3 \\
\hline 9 & 1.3 & 1.0 & 1.0 & - & 1.3 & 4.7 & 4.7 & 3.7 & 2.0 \\
\hline 10 & 0.7 & 0.7 & 0.7 & 1.0 & 1.3 & 5.7 & 12.5 & 6.3 & 3.3 \\
\hline 11 & 0.7 & 0.7 & 1.0 & - & 0.7 & 0.7 & 2.0 & 1.0 & $\cdot 0.7$ \\
\hline 12 & 0.7 & 2.0 & 1.0 & - & 1.3 & 2.3 & 8.0 & 6.3 & 0.7 \\
\hline 13 & 0.7 & 0.7 & 0.7 & 1.0 & 1.3 & 3.7 & 16.0 & 10.7 & 5.3 \\
\hline 14 & 1.0 & 0.7 & 0.7 & 1.0 & 0.5 & 1.3 & 1.3 & 1.3 & 1.3 \\
\hline 15 & 1.0 & 1.0 & 0.7 & 1.0 & 0.7 & 1.0 & 1.0 & - & 1.3 \\
\hline 16 & 0.5 & 1.3 & 0.7 & 1.0 & 1.0 & 1.7 & 6.7 & - & 1.0 \\
\hline 17 & 0.7 & 1.3 & 1.3 & - & - & 3.0 & 4.0 & 2.7 & 1.0 \\
\hline 18 & 1.0 & 1.0 & 0.7 & - & 2.3 & 5.3 & 7.7 & 2.3 & 1.3 \\
\hline 19 & 1.0 & 2.7 & 2.0 & 1.3 & 1.7 & 11.7 & 12.7 & 6.3 & 3.0 \\
\hline 20 & 1.0 & 1.0 & 0.5 & 1.0 & 1.3 & 1.3 & 1.7 & - & 3.0 \\
\hline Mean & 1.3 & 1.5 & 1.2 & 1.5 & 2.3 & 7.3 & 10.7 & 4.7 & 3.5 \\
\hline S.E. & 0.19 & 0.18 & 0.13 & 0.16 & 0.63 & 2.35 & 3.36 & 0.76 & 1.03 \\
\hline $\mathbf{P}$ & & N.S. & N.S. & N.S. & N.S. & $<0.05$ & $<0.02$ & $<0.001$ & $<0.05$ \\
\hline
\end{tabular}

N.S.: statistically not significant.

Mean levels were compaired with preanesthetic levels

$556 \mu \mathrm{Eq} / \mathrm{L}$, which was not a significant variation (Table II). The control blood FFA level was $572 \mu \mathrm{Fq} / \mathrm{L}$ which was estimated as 100 per cent. The blood FFA level did not vary either during anaesthesia alone or during surgery as depicted in Table VI.

\section{Discussion}

The present study demonstrated that the plasma growth hormone level was within normal limits (less than $5 \mathrm{~m} \mu \mathrm{g} / \mathrm{ml}$ ) in patients who had received premedication consisting of pentobarbitone, pethidine and atropine. Thiopentone-nitrous oxide anaesthesia over a 45-minute period did not change plasma HGH levels. The plasma нGн level increased to about 8 times the control value one hour after the start of the operation. In contrast, in our previous studies with ether, methoxyflurane, gamma-hydroxybutyrate, and neurolept anaesthesia consisting of droperidol, pethidine, and nitrous oxide, plasma HGI levels were significantly elevated after 45 minutes of anaesthesia. ${ }^{1,2,12,13}$ 


\section{Plasma Levels of $\mathrm{HGH}$ and Insulin During Thiopent. $-\mathrm{N}_{2} \mathrm{O}$ Anesthesia and Surgery}
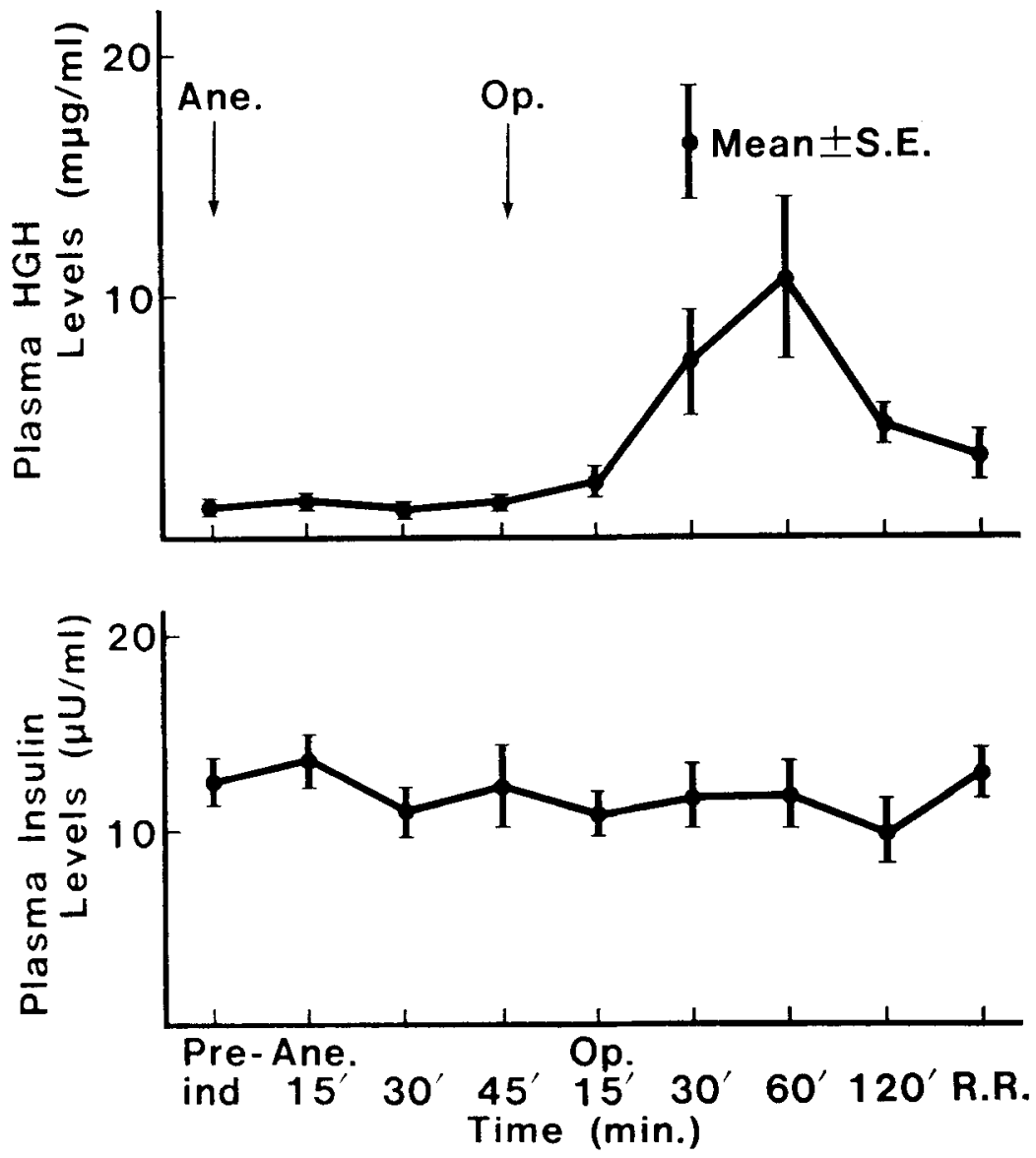

Figure 1

Since growth hormone is considered to be one of the "stress hormones", our data would suggest that thiopentone nitrous oxide appears not to be a stressful technique of anaesthesia, as judged from its influence on growth hormone. It is also interesting to point out that Oyama et al. ${ }^{14}$ demonstrated that thiopentone nitrous oxide anaesthesia for 45 minutes did not stimulate adrenocortical function.

Ketterer et al., ${ }^{15}$ Schalch, ${ }^{6}$ and Charters et al. ${ }^{16}$ studied the effects of surgery on HGH, but they did not evaluate the influence of anaesthesia alone. Like us, they found a transient acute peak of HGH in plasma one hour after the start of operation, but the degree of rise in plasma $\mathbf{H G H}$ during surgery was approximately the same regardless of the type of anaesthetic agent used.

Growth hormone of the anterior pituitary is an anabolic hormone which increases the uptake and synthesis of amino acids. It also has diabetogenic and anti-insulin 


\section{Plasma Insulin Levels During Thiopental- $\mathrm{N}_{\mathbf{2}} \mathrm{O}$ Anesthesia and Surgery}

\begin{tabular}{|c|c|c|c|c|c|c|c|c|c|}
\hline \multirow{2}{*}{ Subjects } & \multicolumn{9}{|c|}{ Plasma Insulin Levels $(\mu \mathrm{U} / \mathrm{ml})$} \\
\hline & Pre-ind & Ane 15' & $30^{\prime}$ & $45^{\prime}$ & Op. $15^{\prime}$ & $30^{\prime}$ & $60^{\prime}$ & $120^{\prime}$ & R.R. \\
\hline 1 & 30.0 & 25.0 & 28.3 & 18.3 & - & 18.3 & 15.0 & - & 18.3 \\
\hline 2 & 16.7 & 11.7 & 11.7 & 一 & 8.3 & 13.3 & 15.0 & - & 15.0 \\
\hline 3 & 23.3 & 6.7 & 10.0 & 15.0 & - & 8.3 & 13.3 & 一 & 10.0 \\
\hline 4 & 20.0 & 23.0 & 21.7 & 23.3 & 16.7 & 25.0 & 23.3 & - & 10.0 \\
\hline 5 & 6.7 & 20.0 & 23.3 & 23.3 & 8.3 & 11.7 & 8.6 & 5.0 & 21.7 \\
\hline 6 & 11.7 & 10.0 & 8.3 & 11.7 & 5.0 & 10.0 & 8.3 & 11.7 & 11.7 \\
\hline 7 & 5.0 & 5.0 & 5.0 & 11.7 & 18.3 & 5.0 & 5.0 & 5.0 & 16.7 \\
\hline 8 & 8.3 & 8.3 & 13.3 & - & 11.7 & 16.7 & 11.7 & 15.0 & 20.0 \\
\hline 9 & 8.3 & 15.0 & 16.7 & - & 8.3 & 15.0 & 13.3 & 8.3 & 20.0 \\
\hline 10 & 3.3 & 3.0 & 5.0 & 3.0 & 3.3 & 5.0 & 5.0 & 8.3 & 6.7 \\
\hline 11 & 3.0 & 8.3 & 3.0 & - & 8.3 & 6.7 & 3.0 & 5.0 & 3.0 \\
\hline 12 & 10.0 & 3.0 & 3.0 & - & 11.7 & 3.0 & 20.0 & 26.7 & 20.0 \\
\hline 13 & 13.3 & 6.7 & 6.7 & 5.0 & 13.3 & 13.3 & 3.0 & 3.0 & 11.7 \\
\hline 14 & 6.7 & 18.3 & 7.0 & 6.5 & 10.0 & 5.0 & 18.3 & 15.0 & 7.0 \\
\hline 15 & 18.3 & 5.0 & 5.0 & 5.0 & 7.0 & 7.0 & 7.0 & - & 15.0 \\
\hline 16 & 20.0 & 26.7 & 7.0 & 13.3 & 20.0 & 25.0 & 7.0 & - & 10.0 \\
\hline 17 & 8.3 & 26.7 & 8.3 & - & - & 15.0 & 11.7 & 6.7 & 8.3 \\
\hline 18 & 11.7 & 11.7 & 15.0 & - & 13.3 & 11.7 & 11.7 & 10.0 & 11.7 \\
\hline 19 & 10.0 & 23.3 & 15.0 & 16.7 & 10.0 & 13.3 & 16.8 & - & 5.0 \\
\hline 20 & 15.0 & 15.0 & 10.0 & 6.7 & 10.0 & 6.7 & 6.7 & 6.7 & 18.3 \\
\hline Mean & 12.5 & 13.6 & 11.2 & 12.3 & 10.8 & 11.8 & 11.2 & 9.7 & 13.0 \\
\hline S.E. & 1.55 & 1.78 & 1.53 & 1.83 & 1.05 & 1.37 & 1.25 & 1.68 & 1.22 \\
\hline $\mathbf{P}$ & & N.S. & N.S. & N.S & N.S. & N.S. & N.S. & N.S. & N.S. \\
\hline
\end{tabular}

N.S.: statistically not significant.

Mean levels were compaired with preanesthetic levels

effects. It enhances mobilization of fatty acids from adipose tissue and increases FFA in blood. Under non-stress states in man, secretion of HGH has been shown to be suppressed by glucose administration and markedly increased by hypoglycaemia. ${ }^{17}$ There is an inverse relation between the plasma concentration of insulin and growth hormone. The increase in growth hormone levels during operation was not influenced by blood glucose or insulin concentrations, but was most likely attributable to surgical stress through the hypothalamic-anterior pituitary axis. Thiopentone nitrous oxide anaesthesia appears to fail to block the activation of this neuroendocrine pathway.

The plasma insulin level is elevated by glucose administration under non-stress conditions. ${ }^{17}$ We demonstrated this in the control group (Table II), as did Allison et al. ${ }^{7}$ But under the influence of thiopentone nitrous oxide anaesthesia, plasma insulin level did not change during operation. 


\section{Plasma FFA and Blood Glucose Levels During Thiopent.- $\mathrm{N}_{2} \mathrm{O}$ Anesthesia and Surgery}
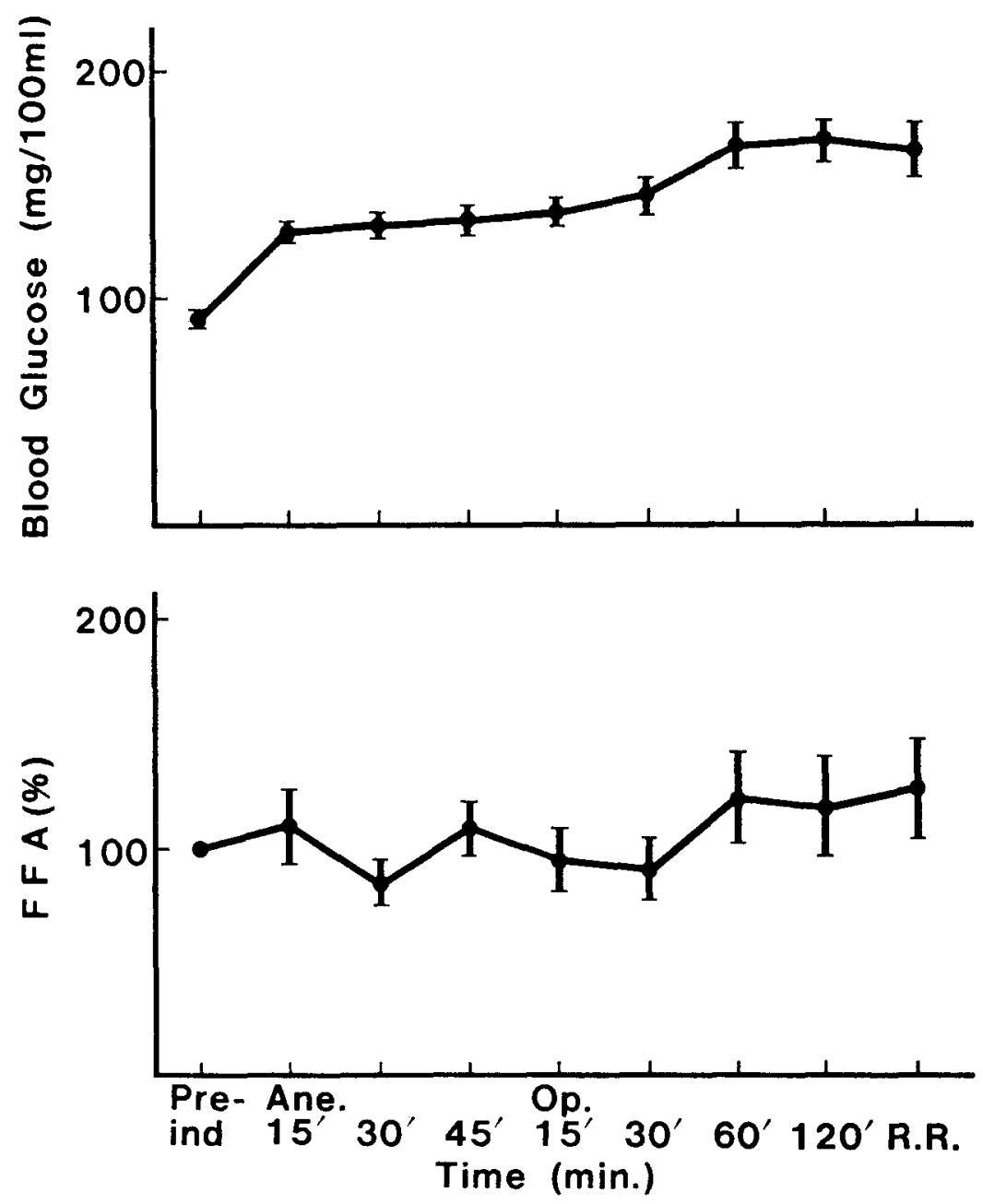

FigURE 2

Blood glucose rose significantly during the period of anaesthesia alone, during operation and in the postoperative period. Infusion of dextran containing 5 per cent glucose would have contributed to this phenomenon. There was no appreciable difference between the control and anaesthetized groups in the rate of increase in blood glucose for 45 minutes during glucose infusion (Tables II, V). This would indicate that thiopentone nitrous oxide does not cause glucose intolerance, which differs from the opinion of Henneman et al. ${ }^{3}$ who showed decreased glucose tolerance to glucose infusion.

The blood FFA did not vary during anaesthesia or surgery. Clarke ${ }^{4}$ reported that FFA appeared to fall during this anaesthetic technique without surgery, changed 
TABLE V

\section{Blood Glucose Levels During Thiopental- $\mathrm{N}_{2} \mathrm{O}$ Anesthesia and Surgery}

\begin{tabular}{|c|r|r|r|r|r|r|r|r|r|}
\hline \multirow{2}{*}{ Subjects } & \multicolumn{8}{|c|}{ Blood Glucose Levels (mg/100ml) } \\
\cline { 2 - 9 } & Pre-ind & Ane 15 & $30^{\prime}$ & $45^{\prime}$ & Op. 15' & $30^{\prime}$ & $60^{\prime}$ & $120^{\prime}$ & R.R. \\
\hline 1 & 98.0 & 134.0 & 139.0 & 150.0 & - & 102.0 & 198.0 & - & 155.0 \\
2 & 95.0 & 132.0 & 167.0 & - & 194.0 & 212.0 & 243.0 & - & 320.0 \\
3 & 103.0 & 99.0 & 112.0 & 151.0 & - & 175.0 & 241.0 & - & 189.0 \\
4 & 96.0 & 146.0 & 183.0 & 157.0 & 137.0 & 145.0 & 177.0 & - & 146.0 \\
5 & 88.0 & 177.0 & 155.0 & 161.0 & 149.0 & 145.0 & 135.0 & 175.0 & 183.0 \\
6 & 96.0 & 108.0 & 121.0 & 123.0 & 129.0 & 123.0 & 130.0 & 166.0 & 143.0 \\
7 & 86.0 & 126.0 & 155.0 & 143.0 & 139.0 & 142.0 & 147.0 & 153.0 & 159.0 \\
8 & 78.0 & 165.0 & 146.0 & - & 174.0 & 186.0 & 226.0 & 187.0 & 277.0 \\
9 & 84.0 & 118.0 & 105.0 & - & 140.0 & 107.0 & 116.0 & 151.0 & 104.0 \\
10 & 73.0 & 104.0 & 93.0 & 90.0 & 102.0 & 131.0 & 135.0 & 143.0 & 158.0 \\
11 & 96.0 & 126.0 & 113.0 & - & 122.0 & 131.0 & 146.0 & 200.0 & 160.0 \\
12 & 105.0 & 121.0 & 136.0 & - & 142.0 & 156.0 & 184.0 & 178.0 & 127.0 \\
13 & 98.0 & 150.0 & 162.0 & 168.0 & 170.0 & 208.0 & 230.0 & 184.0 & 179.0 \\
14 & 80.0 & 141.0 & 120.0 & 115.0 & 115.0 & 130.0 & 122.0 & 125.0 & 136.0 \\
15 & 94.0 & 127.0 & 122.0 & 120.0 & 124.0 & 175.0 & 193.0 & - & 167.0 \\
16 & 88.0 & 112.0 & 106.0 & 110.0 & 120.0 & 112.0 & 110.0 & - & 112.0 \\
17 & 103.0 & 142.0 & 142.0 & - & - & 132.0 & 157.0 & 142.0 & 137.0 \\
18 & 95.0 & 103.0 & 113.0 & - & 121.0 & 130.0 & 209.0 & 207.0 & 153.0 \\
19 & 90.0 & 158.0 & 151.0 & 142.0 & 148.0 & 143.0 & 143.0 & - & 154.0 \\
20 & 98.0 & 135.0 & 132.0 & 129.0 & 124.0 & 135.0 & 135.0 & 192.0 & 146.0 \\
\hline Mean & 92.2 & 131.1 & 133.7 & 135.3 & 138.2 & 146.0 & 168.9 & 169.5 & 165.3 \\
S.E. & 1.89 & 4.66 & 5.21 & 6.10 & 5.54 & 6.71 & 9.52 & 6.67 & 11.06 \\
P & & $<0.001$ & $<0.001$ & $<0.001$ & $<0.001$ & $<0.001$ & $<0.001$ & $<0.001$ & $<0.001$ \\
\hline
\end{tabular}

N.S.: statistically not significant

Mean levels were compared with preanesthetic levels

little during body surface surgery, and rose during intra-abdominal surgery. Therefore, our present study does not accord with their findings.

The clinical significance of the present study is the implication that thiopentone nitrous oxide anaesthesia is the choice of anaesthetic method for diabetic patients, due to its beneficial effect on carbohydrate and fat metabolism.

\section{Summary and Conclusion}

The present study was undertaken to investigate the effects of thiopentone nitrous oxide anaesthesia alone on carbohydrate and fat metabolism in 33 subjects, by determining plasma growth hormone ( $\mathrm{HGH}$ ), insulin, blood glucose and free fatty acids (FFA), and to compare these with the effects of anaesthesia plus surgery. Determination of plasma growth hormone and insulin levels was made by radioimmunoassay utilizing $\mathrm{I}^{125}$ labelled hormones.

Determinations of plasma HGH, insulin, blood glucose, and FFA were made simultaneously before induction of thiopentone nitrous oxide anaesthesia; 15, 30, and 45 minutes after induction of anaesthesia; 15, 30, 60, and 120 minutes after the start of surgery, and in the postoperative period when the patient was adequately awake in the recovery room. 


\section{Plasma FFA Levels During Thiopental- $\mathrm{N}_{\mathbf{2}} \mathrm{O}$ Anesthesia and Surgery}

\begin{tabular}{|c|c|c|c|c|c|c|c|c|c|}
\hline \multirow{2}{*}{ Subjects } & \multicolumn{9}{|c|}{ Plasma FFA Levels (\%) } \\
\hline & Pre-ind & Ane 15 & $30^{\prime}$ & $45^{\prime}$ & Op. 15 & $30^{\prime}$ & $60^{\prime}$ & $120^{\prime}$ & R.R. \\
\hline 1 & 100 & 77.3 & 45.4 & 52.1 & - & 143.3 & 91.2 & - & 107.6 \\
\hline 2 & 100 & 107.8 & 123.7 & - & 111.5 & 120.6 & 120.2 & - & 49.4 \\
\hline 3 & 100 & 51.1 & 44.9 & 70.7 & - & 49.5 & 75.4 & - & 101.6 \\
\hline 4 & 100 & 126.2 & 71.4 & 95.2 & 29.8 & 42.9 & 258.3 & - & 261.9 \\
\hline 5 & 100 & 104.4 & 112.8 & 215.0 & 61.7 & 61.7 & 57.2 & 155.0 & 67.8 \\
\hline 6 & 100 & 78.3 & 30.0 & 89.1 & 36.4 & 38.1 & 60.3 & 39.5 & 48.8 \\
\hline 7 & 100 & 400.0 & 203.9 & 100.0 & 221.9 & 52.3 & 216.1 & 221.9 & 434.2 \\
\hline 8 & 100 & 91.4 & 23.8 & - & 28.7 & 28.7 & 66.0 & 20.5 & 48.0 \\
\hline 9 & 100 & 36.8 & 39.6 & - & 46.5 & 49.9 & 62.8 & 47.4 & 52.8 \\
\hline 10 & 100 & 251.7 & 122.5 & 140.4 & 192.1 & 286.5 & 474.2 & 311.2 & 251.7 \\
\hline 11 & 100 & 118.4 & 139.8 & -- & 79.3 & 126.3 & 124.3 & 202.0 & 103.9 \\
\hline 12 & 100 & 100.0 & 100.0 & - & 123.2 & 100.0 & 158.1 & 105.6 & 141.6 \\
\hline 13 & 100 & 36.9 & 43.7 & 82.8 & 67.1 & 90.3 & 71.1 & 47.9 & 54.7 \\
\hline 14 & 100 & 83.7 & 77.7 & 100.0 & 148.8 & 153.5 & 100.0 & 134.4 & 148.8 \\
\hline 15 & 100 & 107.4 & 92.1 & 99.6 & 79.3 & 92.1 & 76.9 & - & 87.2 \\
\hline 16 & 100 & 89.1 & 78.2 & 82.8 & 87.0 & 108.8 & 77.2 & - & 89.1 \\
\hline 17 & 100 & 89.6 & 102.1 & - & - & 26.5 & 45.5 & 95.5 & 36.7 \\
\hline 18 & 100 & 43.6 & 70.8 & - & 39.6 & 52.0 & 54.0 & 50.0 & 66.4 \\
\hline 19 & 100 & 72.8 & 103.9 & 200.0 & 143.9 & 92.3 & 100.0 & - & 114.2 \\
\hline 20 & 100 & 95.9 & 79.9 & 100.0 & 121.6 & 105.7 & 143.8 & 105.7 & 255.7 \\
\hline Mean & 100 & 108.1 & 85.3 & 109.8 & 95.2 & 91.1 & 121.6 & 118.2 & 126.1 \\
\hline S.E & & 17.94 & 9.48 & 12.75 & 13.48 & 13.04 & 21.74 & 22.80 & 22.05 \\
\hline$P$ & & N.S. & $<0.05$ & N.S. & N.S. & N.S. & N.S. & N.S & N.S. \\
\hline
\end{tabular}

N.S. : statistically not significant

Mean levels were conpaired with preanesthetic levels

Plasma HGH levels were not changed appreciably $(1.5 \mathrm{~m} \mu \mathrm{g} / \mathrm{ml})$ during thiopentone nitrous oxide alone for 45 minutes. They increased and reached a peak (10.7 $\mathrm{m} \mu \mathrm{g} / \mathrm{ml}$ ) one hour after the start of operation. Plasma insulin levels increased in the control group, but they did not change appreciably during anaesthesia or surgery.

Blood glucose levels were increased by glucose load during anaesthesia, but the magnitude of elevation in blood glucose was similar to that of control group, which indicates absence of hyperglycaemic effect of thiopentone anaesthesia. Blood glucose increased significantly during surgery. Plasma fra levels did not change significantly during the entire course of anaesthesia or surgery. These findings suggest that thiopentone-nitrous oxide anaesthesia is the method of choice for diabetic patients.

\section{RÉSUMÉ}

Nous avons entrepris cettc étude, chez 39 sujets, pour étudier les effets de l'anesthésie au thiopentone et au protoxyde d'azote seuls sur le métabolisme des hydrates 
de carbone et des graisses, en déterminant le taux dans le plasma des hormones (HGH), de linsuline, du glucose sanguin et des acides gras libres (FFA) et pour comparer ces effets aux effets de l'anesthésie et de la chirurgie. La détermination des taux d'hormones et d'insuline a été faite par radioimmunoassay en utilisant des hormones marquées à l'I ${ }^{125}$.

Les déterminations des taux d'hormone dans le plasma, de l'insuline du glucose sanguin et des acides gras libres ont été faites simultanément avant linduction de l'anesthésie au thiopentone et au protoxyde d'azote; 15,30 , et 45 minutes après l'induction de l'anesthésie; $15,30,60$, et 120 minutes après le début de la chirurgie et, au cours des suites opératoires, à la salle de réveil, au moment où le malade était bien réveillé.

Après 45 minutes, les taux d'hormones plasmatiques n'ont pas changé de façon appréciable $(1.5 \mathrm{~kg} / \mathrm{ml})$ durant l'anesthésie seule au thiopentone et au protoxyde d'azote. Toutefois, une heure après le début de la chirurgie elles ont atteint un sommet $(10.7 \mathrm{~kg} / \mathrm{ml})$. Chez le groupe de contrôle, les taux d'insuline plasmatique ont augmenté, mais ils n'ont pas varié beaucoup durant l'anesthésie et la chirurgie.

Les taux de glucose sanguin ont été augmentés par une surcharge de sucre durant l'anesthésie, mais le degré d'élévation du glucose sanguin était le même que celui du groupe de contrôle, ce qui indique une absence d'effet hyperglycémiant de l'anesthésie au thiopentone. Les taux d'acides gras libres plasmatiques n'ont pas varié de façon significative durant l'épreuve entière soit de l'anesthésie soit de la chirurgie. Ces résultats nous portent à croire que l'anesthésie au thiopentone et protoxyde d'azote est une méthode de choix pour les diabétiques.

\section{REFERENCES}

1. Oyama, T. \& Takazawa, T. Effect of Methoxyflurane Anaesthesia and Surgery on Human Growth Hormone and Insulin Levels in Plasma. Canad. Anaesth. Soc. J., 17: 347 (1970).

2. Oyama, T. \& Takazawa, T. Effect of Diethyl Ether Anaesthesia and Surgery on Carbohydrate and Fat Metabolism in Man. Canad. Anaesth. Soc. J., 18: 51 (1971).

3. Henneman, D. H. \& Bunker, J. P. Effects of General Anaesthesia on Peripheral Blood Levels of Carbohydrate and Fat Metabolites and Serum Inorganic Phosphorus. J. Pharmacol. \& Exper. Therap., 133: 253 (1961).

4. Clarke, R. S. J. Clinical Studies of Induction Agents. xxiv: The Influence of Anaesthesia with Thiopentone and Propanidid on the Blood Sugar Level. Brit. J. Anaesth., 40: 46 (1968).

5. Glick, S. M.; Roth, J.; Yalow, R. S.; \& Berson, S. A. The Regulation of Growth Hormone Secretion. Recent Progr. Hormone Res., 21: 241 (1965).

6. Sснацсн, D. S. The Influence of Physical Stress and Exercise on $\mathrm{GH}$ and Insulin Secretion in Man. J. Lab. \& Clin. Med., 69: 256 (1967).

7. Allison, S. P.; Tomlin, P. J.; \& Chamberlain, M. J. Some Effects of Anaesthesia and Surgery on Carbohydrate and Fat Metabolism. Brit. J. Anaesth., 41: 588 (1969).

8. Schalch, D. S. \& Parker, M. L. A Sensitive Double Antibody Immunoassay for Human Growth Hormone in Plasma. Nature, 203: 1141 (1964).

9. Morgan, C. R. \& Lazarow, A. Immunoassay of Insulin: Two Antibody System. Diabetes, 12: 115 (1963).

10. Somogyı, M. Notes on Sugar Determination. J. Biol. Chem., 195: 19 (1952).

11. Duncombe, W. G. The Colorimetric Microdetermination of Long-Chain Fatty Acids. Biochem. J., 88: 7 (1963).

12. Oyama, T. \& TAKIGUCHI, M. Effects of Gamma-Hydroxybutyrate and Surgery on Plasma Human Growth Hormone and Insulin Levels. Agressologie, 11: 289 (1970).

13. Oyama, T. \& TAKiguchi, M. Effects of Neuroleptanaesthesia on Plasma Levels of Growth Hormone and Insulin. Brit. J. Anaesth., 42: 1105 (1970). 
14. Oyama, T.; Takiguchi, M.; Aoki, N.; \& Kudo, T. Adrenocortical Function related to Thiopental- $\mathrm{N}_{2} \mathrm{O}$ Anaesthesia and Surgery in Man. Anesth. \& Analg. (in press).

15. Ketterer, H.; Poweld, D.; \& Unger, R. H. Growth Hormone Response to Surgical Stress. Clin. Res., 14: 65 (1966).

16. Charters, A. C.; Odell, W. D.; \& Thompson, J. C. Anterior Pituitary Function during Surgical Stress and Convalescence: Radioimmunoassay Measurements of Blood TSH, LH, FSH, and Growth Hormone. J. Clin. Endocrinol., 29: 63 ( 1969).

17. Williams, R. H. Textbook of Endocrinology 4th ed. pp. 624, 662, Philadelphia: Saunders (1968). 